\title{
Cytotoxic Activity on Brine Shrimp, MCF-7 Cell Line and Thrombolytic Potential: Seven Different Medicinal Plant Leaves Extract
}

\author{
A. K. Azad ${ }^{1 *}$, M. A. Jainul ${ }^{1}$, Z. K. Labu ${ }^{2 *}$ \\ ${ }^{1}$ Department of Pharmaceutical Technology, Faculty of Pharmacy, International Islamic University \\ Malaysia, 25200 kuantan, Pahang, Malaysia \\ ${ }^{1}$ Department of Biomedical Science, Faculty of Allied Health Science, International Islamic \\ University Malaysia, 25200 kuantan, Pahang, Malaysia \\ ${ }^{2}$ Department of Pharmacy, World University of Bangladesh, 151/8, Green Road, Dhaka-1205 \\ Received 6 December 2017, accepted in final revised form 8 February 2018
}

\begin{abstract}
The aim of our study was to find out the preliminary cytotoxic and thrombolytic effect of the seven selected medicinal plant leaves extract. In cytotoxic activity, out of the seven leaves extract three of them exhibited stronger brine shrimp lethality with $\mathrm{LC}_{50} 122.548$ (Uncaria acida), 170.861 (Leea indica) and 175.469 (Piper porphyrophyllum) $\mu \mathrm{g} / \mathrm{mL}$ respectively, and on MCF-7 cell line, they also exhibited moderate cytotoxic activity with different concentration of the extract of the same plant leaves such as, Uncaria acida (72.31, 56.22, 38.12 and 9.24\%), Leea indica (67.31, 58.22, 43.12 and 15.24\%), Piper porphyrophyllum $(65.88,48.12,40.12$ and $21.34 \%)$. In thrombolytic assessments, all the leaves extract showed moderate (considering $>20 \%$ moderate; $* * p<0.01 ; * p<0.05$ ) clot lysis activity, but among the extracts, Uncaria cordata $(27.36 \pm 0.10 \%)$ showed the highest and Stachytarpheta indica the lowest $(6.14 \pm 0.20 \%)$ percent clot lysis as compared with the standard streptokinase $(65.15 \pm 0.16 \%)$. This study was conducted to legalize the folkloric use of seven medicinal plant leaves.
\end{abstract}

Keywords: Cytotoxicity; Brine shrimp; Lethality bioassay; MCF-7 cell line; Thrombolytic potential.

(C) 2018 JSR Publications. ISSN: 2070-0237 (Print); 2070-0245 (Online). All rights reserved. doi: http://dx.doi.org/10.3329/jsr.v10i2.34820 J. Sci. Res. 10 (2), 175-185 (2018)

\section{Introduction}

Medicinal plants always provide new substances, e.g. antibiotics, alkaloids, cardiac glycosides, quinines, phenols, flavonoids and saponins, which have many biologiactive

\footnotetext{
*Corresponding author: azad2011iium@gmail.com; zubair.labu@yahoo.com
} 
functions [1]. Above bioactive compounds are effective in many systemic and nonsystemic ailments, such as heart disease, diabetes, kidney disease etc. Since ancient era, herbs are being used for the treatment, curing and prevention of many diseases and symptoms traditionally among indigenous people and civilized society as well, without knowing its toxicity or side effects. Thrombosis is an internecine disease which is manifested by the development of a blood clot (thrombus) in the circulatory system because of the inconsistency of homeostatic system of the body. It leads to vascular blockade and while recovering causes deadly outcomes, such as myocardial infarction and even death [2]. Streptokinase is widely used as fibrinolytic drug and was used in this study as reference. Generally, this drug which breaks the thrombus, works by activating the enzyme plasminogen to plasmin that clears the cross linked fibrin mesh [3]. In practice, either the herbs themselves or the crude extracts are used for traditional remedies but not the isolated molecules. Therefore, the importance of toxicity and clot lysis study of the crude extract is beyond description.

Piper porphyrophyllum: Tiger's betel is an endemic plant of Malaysia. This plant was collected from Kelantan, Malaysia, in 2004 and is known as Sireh Rimau (tiger's betel). Traditionally, this wild Piper was purportedly effective against leprosy, stomach aches in children and a variety of skin diseases. It is also used for postpartum aid, and to treat bone aches and pains. Antibacterial activity of the leaf extract of this plant has been reported. Seven flavonoid compounds have been isolated from the aerial parts of tiger's betel (Piper porphyrophyllum), which were identified as 5,7-dimethoxyflavone, 4',5,7trimethoxy-flavone, $3^{\prime}, 4^{\prime}, 5,7$ tetramethoxy flavone, 4'-hydroxy-3',5,7-trimethoxy flavone, 5-hydroxy-3',4',7 trimethoxy flavone, 4',5-dihydroxy-3',7-dimethoxy flavone and 5hydroxy-7 methoxy flavanone [4]. It has various biological activities including antifungal, antimalarial, anti-mycobacterial, anti-inflammatory, Anticholinesterase and antityrosinase and antioxidant activity [5].

Uncaria (Rubiaceae): The Uncaria genus is an important source of medicinal natural products, particularly alkaloids and triterpenes. Pharmacological studies are described according to cytotoxicity, anti-inflammatory, antiviral, immune stimulation, antioxidant, CNS-related response, vascular, hypotensive, mutagenicity and antibacterial properties. The potential for development of leads from Uncaria continues to grow, particularly in the area of immunomodulatory, anti-inflammatory and vascular-related conditions [6]. Uncaria (Rubiaceae) is amongst the genera known for its alkaloid content. The majority of alkaloids founds in Uncaria are of the indole and oxindole type [7]. Out of 14 species of Uncaria available in Malaysia, Uncaria cordata var. ferruginea is one of the most common representatives. This species of Uncaria comprises of two major entities namely, Uncaria cordata var. ferruginea and Uncaria cordata var. cordata. A total of eight alkaloids have been found in Uncaria cordata, including dihydrocorynantheine, corynoxine, corynoxine B, 3-epi- $\beta$-yohimbine, rhynchophylline, isorhyncophylline, uncarine A and uncaric acid D [8].

Scaphium macropodum: Scaphium macropodum (Miq.) Beumée ex K. Heyne. (Malvaceae) or malva nut is mostly found in Myanmar, Cambodia, Laos, Vietnam, 
Thailand, Peninsular Malaysia, Sumatra, and Borneo (throughout the island). In Central Thai called Samrong or Pungtalai while the Northeastern Thai called Makjong. It flowering and fruiting every 3-4 years. Soaked Makjong fruits formed a large quantity of gel that has many medicinal applications such as against intestinal infections, diarrhea, constipation, throat aches, asthma, dysentery, fever, coughs, inflammation for urinary ailments. Some people drink Makjong juice as a dietary beverage because of its cooling property [9].

Uncaria acida: Uncaria tomentosa (Willd.) DC., usually known as "uña de gato" or "cat's claw," belongs to the Rubiaceae family and has been used for centuries by the Asháninkas indigenous people. Dietary supplements derived from cat's claw bark have been used extensively worldwide as a complementary therapy for the treatment of inflammatory diseases and cancer. Phytochemical studies have shown that $U$. tomentosa bark presents three main fractions of secondary metabolites, polyphenols, alkaloids and triterpene derivatives, which have all been suggested to have antitumor effects. Some studies have suggested that $U$. tomentosa can inhibit the proliferation of several cancer cell lines, such as cervical carcinoma, breast cancer, osteosarcoma and leukemia, and cell death appears to be mediated through caspase-dependent apoptosis [10].

Antidesma cuspidatum: Antidesma is a tropical plants genus classified in family Phyllanthaceae (Malpighiales, Euphorbiaceae sensu lato). Most of the genus in South-East Asia is commonly found in the understory of tropical forests as well as in open vegetation. They have approximately 170 Antidesma species in the world including South-East Asia. Antidesma cuspidatum M.A. is one of the species of Antidesma, which is largely distributed in Malaysia, Borneo, and Indonesia, especially in Sulawesi. The leaves of "Kenida punai", an Indonesia local name of A. cuspidatum, have been applied as traditional carminative medicine. Recently researchers were discovered its anticancer activity [11].

Stachytarpheta indica: Stachytarpheta indica Vahl (Verbenaceae) is commonly known as snake weed. A well branched herb, 2-3 ft high with very long narrow spikes; flowers deep blue with white centre. The plant is known by various names in different parts of Nigeria, such as 'Tsarkiyar kuse' (Hausa), 'Iru amure' (Yoruba) [12,13]. It has been used locally as an abortifacient, and in the management of asthma, headache, alopecia, bronchitis, bruises, constipation, diarrhoea, skin sore, dysentery, dysmenorrheal, fever, inflammation, liver disease, poisoning, tumor, venereal diseases, cataract, sedative, anti-fertility and rheumatism [14].

Leea indica: Malaysian rainforests store a large number of plant species which are important as the source of traditional medicine [15]. Leea indica (Vitaceae), commonly known as 'Huo Tong Shu' in Malaysia, have been traditionally used as natural remedy in folk medicine by the locals. It is a perennial shrub which can be found in tropical and subtropical countries, such as Thailand, Malaysia, India and China. The leaves and roots of L. indica are traditionally used for the treatment of cancer, diabetes, diarrhea, dysentery, spasm and skin diseases [16]. 


\section{Materials and Method}

\subsection{Plant identification and collection}

Seven plant leaves were collected from area in Kuantan, Pahang. After that the leaves of the plants were dried in a protech laboratory dryer (FDD-720) at $37^{\circ} \mathrm{C}$ in the dark for 10 days, pulverized to powder using Fritsch Universal Cutting Mill-pulverisette 19, Germany, and stored at $4{ }^{\circ} \mathrm{C}$ until further use.

\subsection{Preparation of ethanolic extract}

Cold maceration was performed using ethanol for $48 \mathrm{~h}$ at room temperature, followed by filtration using adsorbent cotton wool and filter paper (Whatman No. A-1). The extraction using similar solvent was repeated for 4 times to ensure maximum yield of ethanol soluble compounds. The ethanol extract was concentrated in vacuum using a rotary evaporator (BUCHI R-205). The extract was frozen at $-70{ }^{\circ} \mathrm{C}$ and transferred immediately to two weeks' continuous freeze drying at $-50{ }^{\circ} \mathrm{C}$ using bench top freeze dryer (ALPHA 1-4LD2) [17].

\subsection{Preparation of sea water}

38 g sea salt (Sigma Chemical Co., UK) were dissolved in one liter of distilled water, adjusted to $\mathrm{pH} 8.5$ using $1 \mathrm{~N} \mathrm{NaOH} \mathrm{[18].}$

\subsection{Hatching of brine shrimp}

$100 \mathrm{mg}$ of Artemia salina eggs obtained from pet shop were added to a beaker containing $1000 \mathrm{~mL}$ of salt water. The eggs were incubated to hatch for $48 \mathrm{~h}$ at $37{ }^{\circ} \mathrm{C}$ and air pump were used to supply oxygen.

\subsection{Preparation of test solutions}

The extracts ( $8 \mathrm{~g}$ ) were dissolved in $200 \mu \mathrm{L}$ of pure dimethyl sulfoxide (DMSO) and the volume was made to $20 \mathrm{~mL}$ with sea water making the stock solution of $1600 \mu \mathrm{g} / \mathrm{mL}$. Then the solution was serial diluted to $800,400,200,100,50,25,12.5,6.25,3.125$, 1.5625 and $0.78125 \mu \mathrm{g} / \mathrm{mL}$ sea water. Then $2.5 \mathrm{~mL}$ of test solution was added to $2.5 \mathrm{~mL}$ of sea water containing 10 nauplii. Lethality tests were done with initial extracts concentrations of $1000 \mu \mathrm{g} / \mathrm{mL}$ in vials containing $5 \mathrm{~mL}$ of brine and 10 shrimps in each of three replicates.

\subsection{Counting of nauplii}

The bioassay was performed at $27^{\circ} \mathrm{C}$ for $24 \mathrm{~h}$ under illumination [19]. The test vials were inspected using a magnifying glass and the number of survived nauplii in each tube was 
counted. From this data, the percent $(\%)$ of lethality of the brine shrimp nauplii was calculated for each concentration and as compared with the control. The effectiveness or the concentration-mortality relationship of plant product is expressed as a median lethal concentration $\left(\mathrm{LC}_{50}\right)$ value.

\subsection{Cell culture and MTT-assay procedure}

MCF-7 cells were cultured in 25 t-flask and were maintained in Dulbecco's modified Eagle's medium supplemented with $100 \mathrm{IU} / \mathrm{mL}$ penicillin, $100 \mu \mathrm{g} / \mathrm{mL}$ streptomycin, $10 \%$ fetal bovine serum at $37{ }^{\circ} \mathrm{C}$ with $5 \% \mathrm{CO}_{2}, 95 \%$ air and complete humidity [20]. They were detached using $0.05 \%$ trypsin/ethylene diamine tetra acetic acid and counted by means of trypan blue and hemocyto meter when reached $\sim 90 \%$ confluence and then resuspended at a concentration of $4 \times 104 \mathrm{cells} / \mathrm{cm}^{2}$ to add into a 96-well plate (i.e., 250 $\mu \mathrm{L} /$ well) via a channel pipette. Some wells were kept cell-free as blanks (i.e., controls) for background absorption and comparison. The cell viability was assessed by the MTT colorimetric assay which is based on the reduction of MTT by the mitochondrial succinate dehydrogenase of intact cells to a purple formazan product. Briefly, $100 \mu \mathrm{L}$ aliquots of the exponentially growing MCF-7 cells containing $5 \times 104$ cells $/ \mathrm{mL}$ were added to each well of a 96-well flat-micro titer plates and incubated with various concentration of the selected plant's crude extract dissolved in $0.1 \%$ dimethyl sulfoxide (DMSO). Four replicate wells were used in each point in the experiments. After $48 \mathrm{~h}$ incubation at $37^{\circ} \mathrm{C}$, MTT solution $\left(5 \mathrm{mg} / \mathrm{mL}\right.$ in PBS) was added and incubated for another $4 \mathrm{~h}$ at $37{ }^{\circ} \mathrm{C}$ in a $5 \% \mathrm{CO}_{2}$ incubator. The resulting MTT-formazan product was dissolved by the same volume of lysis buffer (10\% SDS- $0.1 \mathrm{M} \mathrm{HCl})$ and the incubation was continued overnight at $37^{\circ} \mathrm{C}$. The amount of formazan was determined by measuring the absorbance at $570 \mathrm{~nm}$ using a Bio-Rad 550 ELISA micro plate reader.

\subsection{Statistical analysis}

The mean results of mortality percentage of the brine shrimp versus the log of concentrations were plotted using the Microsoft Excel, $\mathrm{LC}_{50}$ were calculated using linear regression.

\subsection{In vitro thrombolytic activity}

\subsubsection{Streptokinase (SK) solution preparations}

Lyophilized streptokinase vials of 1500000 I.U commercially available in market. One vial was collected and $5 \mathrm{~mL}$ sterile distilled water was poured, mixed properly by shaking. This suspension was used as a reference stock solution, from which $100 \mu \mathrm{L}$ (30,000 I.U) was used for in vitro thrombolytic potential. 


\subsubsection{Justification of streptokinase use}

Streptokinase is a thrombolytic medication and enzyme. As a medication it is used to break down the blood clots [21].

\subsubsection{In vitro thrombolytic assay procedure}

The crude ethanolic extract (CEE) of seven medicinal plants leaves were assessed for thrombolytic potential by means of human blood, according to the method previously described by Daginawala et al. [22]. In this thrombolytic study, $22 \mathrm{~mL}$ of venous blood was collected from healthy male volunteers and transferred equally into 21 pre-weighed micro sterile centrifuge $1 \mathrm{~mL} /$ tube, (out of which 7 of the centrifuge tubes as denoted ' $\mathrm{A}$ ' type tubes, 7 of them denoted as ' $\mathrm{B}$ ' type tubes and the rest of them denoted as ' $\mathrm{C}$ ' type tubes) followed by incubation (without any disturbance) at room temperature for $45 \mathrm{~min}$ to ensure clot formation. From formed clot, the serum was separated successfully and the tubes were again weighed. The CEE suspension $(2 \mathrm{mg} / 1000 \mu \mathrm{L}$ of water $)$ was poured in every micro centrifuge ' $\mathrm{A}$ ' type tubes, $100 \mu \mathrm{L}$ of streptokinase used as positive control (equivalent to 30,000 I.U.) was poured into every 'B' type tubes and $1000 \mu \mathrm{L}$ of distilled water (used as negative control) into ' $C$ ' type tubes. Then all tubes were allowed to keep at room temperature without any disturbance. After $90 \mathrm{~min}$ of incubation, the soluble supernatant was decanted carefully from the decantation. Tubes were further weighed to measure the clot lysis. The percentage of clot lysis was determined using the following equation:

Clot lysis $(\%)=($ weight of clot after treatment /weight of clot before treatment $) \times 100$

\section{Results and Discussion}

\subsection{Cytotoxicity study}

The cytotoxicity study was done by using brine shrimp nauplii (Artemia salina) and it was considered as an in vivo toxicity test. In this cytotoxic activity study, the different mortality rate of the nauplii was observed in experimental groups. Interestingly, among the seven plants extracts; three plants extracts showed moderate cytotoxic activity with the mortality rate of more than $85 \%$ in average and the linear regression value $\left(\mathrm{R}^{2}\right.$ value $)$ were Piper porphyrophyllum, Uncaria cordata, Scaphium macropodum, Uncaria acida, Antidesma cuspidatum, Stachytarpheta indica and Leea indica (0.898, 0.854, 0.808, $0.868,0.714,0.832$ and 0.896$)$ with the concentration of $175.469,361.124,415.998$, $122.548,391.779,>1000.0$ and $396.861 \mu \mathrm{g} / \mathrm{mL}$. Whereas potassium dichromate was used as a positive control with the concentration of $49.522 \mu \mathrm{g} / \mathrm{mL}\left(\mathrm{R}^{2}\right.$ value, 0.969$)$. This result indicated that among three tested plants extract could be effective for cytotoxic study (Table 1). 
Table 1 . Shows the $\mathrm{LC}_{50}$ values of plant samples through brine shrimp lethality bioassay with linear regression values.

\begin{tabular}{llll}
\hline Plant Ethanolic Extract & Plant Part & $\mathrm{LC}_{50}(\mu \mathrm{g} / \mathrm{mL})$ & $\mathrm{R}^{2}$ value \\
\hline Piper porphyrophyllum & Leaves & 175.469 & 0.898 \\
Uncaria cordata & Leaves & 361.124 & 0.854 \\
Scaphium macropodum & Leaves & 415.998 & 0.808 \\
Uncaria acida & Leaves & 122.548 & 0.868 \\
Antidesma cuspidatum & Leaves & 391.779 & 0.714 \\
Stachytarpheta indica & Leaves & $>1000.0$ & 0.832 \\
Leea indica & Leaves & 170.861 & 0.899 \\
Potassium dichromate & Positive Control & 49.522 & 0.969 \\
\hline
\end{tabular}

\subsection{Brine shrimp lethality bioassay}

The extracts were found as a toxic substance against the brine shrimp nauplii. Therefore, the positive response obtained in this assay suggests that the plant fruits are toxic. Finding of this study showed that three of ethanolic plant extracts exhibited moderate cytotoxicity compare to the rest of tested plants. These three plants could be used for further investigation to determine cytotoxicity and next to more research to look anticancer activity and it could be used as a traditional herbal remedy for anticancer treatment.

\subsection{Cytotoxicity test (MTT-assay)}

In cytotoxicity test (MTT-assay), among seven selected medicinal plants three of them were have moderate cytotoxic activity such as Uncaria acida (72.31, 56.22, 38.12 and $9.24 \%)$, Leea indica (67.31, 58.22, 43.12 and 15.24\%), Piper porphyrophyllum (65.88, $48.12,40.12$ and $21.34 \%$ ) at the treated dose concentrations of $10,40,70$ and $100 \mu \mathrm{M}$, where DMSO $(0.1 \%)$ was used as a vehicle control in this experiment. At the concentration of 70 and $100 \mu \mathrm{M}$ showed more potential and effective compare with 10 and $40 \mu \mathrm{M}$. Cytotoxic findings are presented in Figs. 1-3 respectively. However, rest of them were screened by the same dose and procedure but were not found any positive activities (Fig. 4).

In our study, the different plants of leaves extract were determined as novel anticancer compound by using MTT assays on MCF-7 cell line. Natural products have well reputation to produce the lead compound for the purpose of diseases treatment as folk and traditional remedies. Among seven selected plant extracts; three of them were showed moderate cytotoxic activity where rest of them was not potent for cytotoxic effect. The current study has come out with significant results that will be play a key role in near future for further research. 


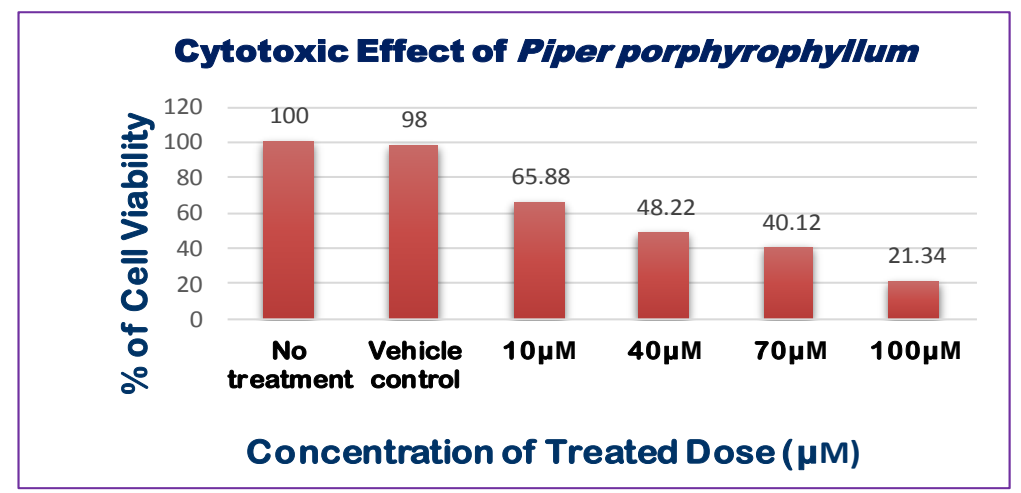

Fig. 1. In vitro cytotoxic effect of Piper porphyrophyllum extract at several concentrations of $10 \mu \mathrm{M}, 40 \mu \mathrm{M}, 70 \mu \mathrm{M}$ and $100 \mu \mathrm{M}$ in MCF-7 Cell.

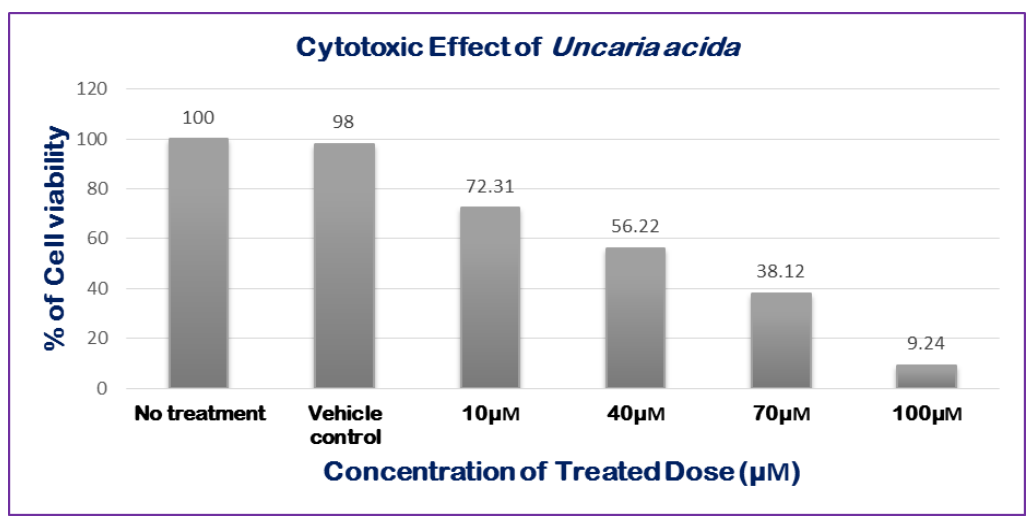

Fig. 2. In vitro cytotoxic effect of Uncaria acida extract at several concentrations of $10 \mu \mathrm{M}, 40$ $\mu \mathrm{M}, 70 \mu \mathrm{M}$ and $100 \mu \mathrm{M}$ in MCF-7 Cell.

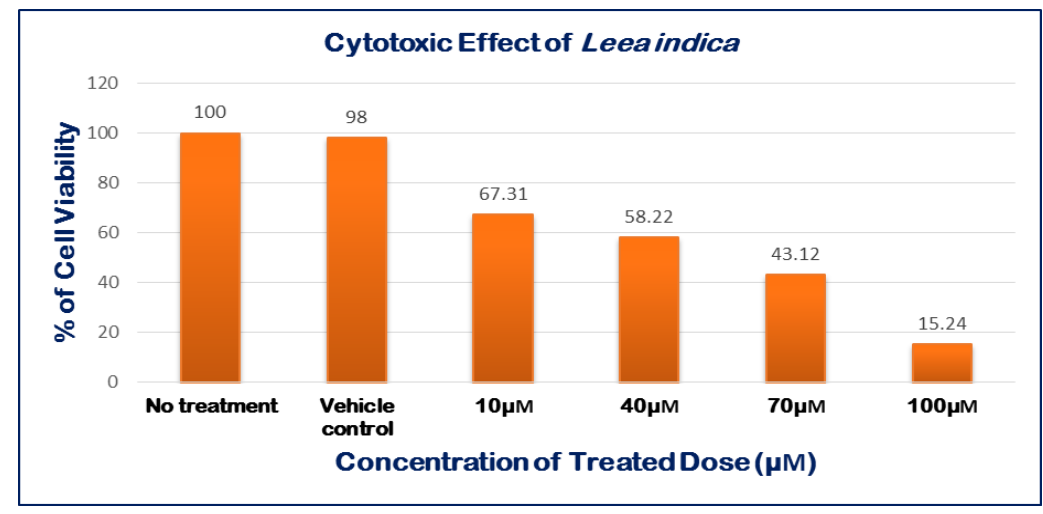

Fig. 3. In vitro cytotoxic effect of Leea indica extract at several concentrations of $10 \mu \mathrm{M}, 40 \mu \mathrm{M}$, $70 \mu \mathrm{M}$ and $100 \mu \mathrm{M}$ in MCF-7 Cell. 


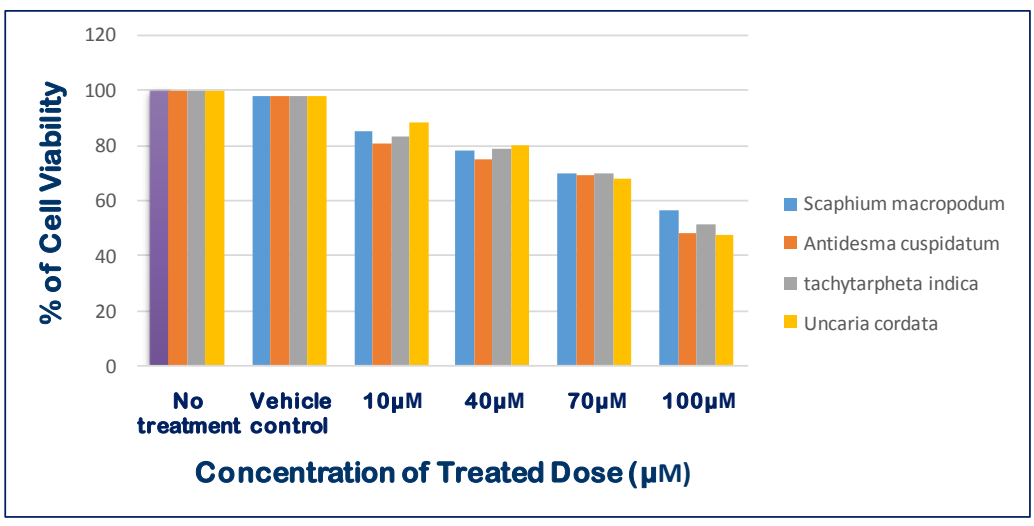

Fig. 4. In vitro cytotoxic effect of Scaphium macropodum, Antidesma cuspidatum, Stachytarpheta indica and Uncaria cordata extract at several concentrations of $10 \mu \mathrm{M}, 40 \mu \mathrm{M}, 70 \mu \mathrm{M}$ and $100 \mu \mathrm{M}$ in MCF-7 Cell.

\subsection{Thrombolytic activity}

Positive control streptokinase [23,24] was used for the assessment of thrombolytic activity which was exhibited significant percent of clot lysis (average value, $65.15 \pm 0.16 \%$ ), whereas, the negative control was showed negligible (average value, $8.20 \pm 0.16 \%$ ) percent of clot lysis. The percentages of clot lysis by seven leaves extract were observed in the following order namely, Uncaria cordata $(27.36 \pm 0.23 \%)$, Antidesma cuspidatum $(21.64 \pm 0.25 \%)$, Scaphium macropodum (20.74 \pm 0.43\%), Uncaria acida (19.90 \pm $0.43 \%)$, Piper porphyrophyllum $(12.88 \pm 0.33 \%)$ respectively. Remaining two leaves extract did not show remarkable percent of clot lysis. Interpreting the result, it may be assumed that (considering $>20 \%$ moderate), $(* * p<0.01 ; * p<0.05)$ medicinal plants leaves extract exhibited moderate thrombolytic activity which are presented in the Table 2 .

Table 2. Thrombolytic activity of crude ethanolic leaves extract of seven medicinal plants.

\begin{tabular}{llc}
\hline Plant ethanolic extract & Plant part & Percent of clot lysis \\
\hline Piper porphyrophyllum & leaves & $12.88 \pm 0.33$ \\
Uncaria cordata & Leaves & $* 27.36 \pm 0.23$ \\
Scaphium macropodum & Leaves & $* 20.74 \pm 0.43$ \\
Uncaria acida & Leaves & $19.90 \pm 0.43$ \\
Antidesma cuspidatum & Leaves & $* 21.64 \pm 0.25$ \\
Stachytarpheta indica & Leaves & $06.14 \pm 0.20$ \\
Leea indica & Leaves & $07.24 \pm 0.15$ \\
SK & - & $* * 65.15 \pm 0.16$ \\
Negative control & - & $8.20 \pm 0.16$ \\
\hline Values are expressed as mean \pm SEM, ${ }^{*} p<0.05, * * p<0.01$, significant when compared with the corresponding \\
value of positive and negative control.
\end{tabular}


Thrombosis process is kicked off by activating platelets and also binding to the leucocytes that brings them into a formation of clot as well as growth of plaque [25]. Plasmin is a fibrinolytic agent by nature. Plasminogen is easily triggered to plasmin, which could cause to fibrinolysis [26]. Streptokinase (a bacterial plasminogen activator) with plasminogen is capable of converting to plasmin [27]. Numerous thrombolytic drugs ( e.g. Streptokinase) have been adapted with recombinant technology to make those thrombolytic drugs more effective and site specific [28], but some adverse effects like bleeding and embolism have been resulted from these drugs, which lead to further complications [29]. Our findings revealed that standard streptokinase exhibited $(65.15 \pm 0.16 \%)$ and negative control $(8.20$ $\pm 0.16 \%$ ) clot lysis while five out of seven test samples have moderate thrombolytic activities as compared with the corresponding value of positive and negative control. They are expressed in the following order: Uncaria cordata $(27.36 \pm 0.23)>$ Antidesma cuspidatum $(21.64 \pm 0.25)>$ Scaphium macropodum $(20.74 \pm 0.43)>$ Uncaria acida $(19.90 \pm 0.43)>$ Piper porphyrophyllum $(12.88 \pm 0.33)$. Considering the above results, it is clear that our research leaves extract is just remedy but not a clear preventive for thrombosis.

\section{Conclusion}

This study was conducted to legalize the seven medicinal plant leaves used as a folk medicine (for the ailment of numerous diseases) such as thrombolytic, membrane stabilizing, cytotoxic activity. The outcomes of this research revealed the potential medicinal properties of leaves extracts of the seven medicinal plants against formation of thrombus, cytotoxic activity on brine shrimp and MCF-7 Cell line. Further comprehensive study can be conducted for the chemical characterization of the corresponding chemical compound responsible for afore mentioned medicinal values.

\section{Acknowledgment}

This study was supported by the International Islamic University Malaysia endowment (EDW B13-065-0950) fund. The authors acknowledged the assistance of Basic Medical Science Department of Kulliyyah Pharmacy, International Islamic University of Malaysia and Department of Pharmacy, World University of Bangladesh.

\section{References}

1. K. Samira, M. Kawsar, F. R. Laboni, A. S. Julie, J. Uddin, and Z. K. Labu, J. Coast Life Medicine 4, 874 (2016). https://doi.org/10.12980/jclm.4.2016J6-175

2. F. A. Nicolini and W. W. Nichols, J. Am. Coll. Cardiol. 20, 228 (1992). https://doi.org/10.1016/0735-1097(92)90164-I

3. R. E. Ahmad and F. Sirat, Nat. Prod. Res. 24(4), 387 (2010). https://doi.org/10.1080/14786410903421826

4. F. S. Ahmad, H. M. Jamaludin, F. Mustapha, N. M. A. Ali, R. M. Arbain, and H. Y. AboulEnein, Arabian J. Chem. 7(6), 1031 (2014). https://doi.org/10.1016/j.arabjc.2010.12.032 
5. M. E. Heitzman, C. C. Neto, E. Winiarz, A. J. Vaisberg, and G. B. Hammond, Phytochem. 66(1), 5 (2005). https://doi.org/10.1016/j.phytochem.2004.10.022

6. N. H. Abdullah, F. Salim, and R. Ahmad, Molecules 21(5), 525 (2016). https://doi.org/10.3390/molecules 21050525

7. M. E. Heitzman, C. C. Neto, E. Winiarz, A. J. Vaisberg, and G. B. Hammond, Phytochemistry 66, 5 (2005). https://doi.org/10.1016/j.phytochem.2004.10.022

8. C. Monton, J. Suksaeree, and P. Pathompak, Int. J. Pharm. Pharm. Sci. 6(6), 610 (2014).

9. F. Dietrich, S. Kaiser, L. Rockenbach, F. Figueiro, L. S. Bergamin, F. M. da Cunha, F. B. Morrone, G. G. Ortega, and A. M. O. Battastini, Toxicology 67, 222 (2014).

10. B. Elya, R. C. Forestrania, M. Ropi, S. Kosela, K. Awang, H. Omar, and A. H. A. Hadi, Records Natural Products 8(4), 342 (2014).

11. E. S. Ayensu, Medicinal Plants of West Africa (1978). pp. 10.

12. H. N. K. Kumar, S.D. Preethi, E. Chandana, and J. B. Chauhan, Int. J. Pharm. Sci. 3, 1684 (2013).

13. C. G. Akuodor, M. P. Udia, C. E. Udenze, and J. O. Ogbonna, Asian J. Medi. Sci. 4(4), 5 (2013).

14. K. Saha, N. H. Lajis, D. A. Israf, A. S. Hamzah, S. Khozirah, S. Khamis, and A. Syahida, J. Ethnopharmacology 92(2), 263 (2004). https://doi.org/10.1016/j.jep.2004.03.007

15. N. S. Reddy, S. Navanesan, S. K. Sinniah, N. A. Wahab, and K. S. Sim, BMC Complementary and Alternative Medicine 12(1), 128 (2012). https://doi.org/10.1186/1472-6882-12-128

16. A. K. Azad, W. M. A. W. Sulaiman, and N. K. Sunzida, J Coast Life Med. 4(1), 45 (2016). https://doi.org/10.12980/jclm.4.2016j5-194

17. A. K. Azad, M. K. Rahman, and N. K. Sunzida, J. Pharmacognosy Phytochem. 4(4), 228 (2015).

18. T. Ahsan, M. Rahman, M. A. Ahmed, and S. B. Uddin, J. Sci. Res. 2(3), 621 (2010). https://doi.org/10.3329/jsr.v2i3.4772

19. M. S. Islam, Y. Kusumoto, and M. A. Al-Mamun, J. Sci. Res. 3(2), 375 (2011). https://doi.org/10.3329/jsr.v3i2.5162

20. Q. Y. Wei, J. P. Ma, Y. J. Cai, L. Yang, and Z. L. Liu, J. Ethnopharmacology 102(2), 177 (2005). https://doi.org/10.1016/j.jep.2005.05.043

21. N. Sikri and A. Bardia, Tex. Heart Inst. J. 34 (3), 318 (2007).

22. S. Prasad, R. S. Kashyap, J. Y. Deopujari, H. J. Purohit, G. M. Taori, and H. F. Daginawala, Thrombosis J. 4, 14 (2006). https://doi.org/10.1186/1477-9560-4-14

23. R. L. Farhina, K. Samira, and K. L. Zubair, Dhaka Univ. J. Pharm. Sci. 15, 173 (2016).

24. K. Samira, S. I. Md, T. Zarin, R. L. Farhina, S. J. Azima, and K. L. Zubair, Open Bioact. Compds. J. 4, 36 (2017). https://doi.org/10.2174/1874847301704010036

25. C. R. M. Prentice, Eur. Heart J. Suppl. 1, 3 (1999).

26. M. Pantzar, A. Ljungh, and T. Wadström, Infect. Immun. 66, 4976 (1998).

27. A. Banerjee, Y. Chisti, and U. C. Banerjee, Biotechnol. Adv. 22, 287 (2004). https://doi.org/10.1016/j.biotechadv.2003.09.004

28. S. Liu, J. E. Manson, I. M. Lee, S. R. Cole, C. H. Hennekens, W. C. Willett, and J. E. Buring, Am. J. Clin Nutr. 72, 922 (2000).

29. A. S. Gallus, Clin. Haematology 11, 663 (1998). 